\title{
180 2นnafreons
}

\section{LXVII.}

9Peptunus Monat ift erfdbienen;

JL Die 2 Bolfen bången fotwer von พSaffern;

Ind wilbe Stitrme rajen beulend.

Diefer Monat ber (Brieçen fängt nađ unferm Eas Jenber mit ber anbern selfte bes Coriftmounates an und enbiget fid mit Der exftern Des Jenners. 